\title{
Dealing with Diversity: Factors discouraging participation of Māori and Pacifica females in ICT education
}

\author{
Scott Morton \\ Whitireia Polytechnic
}

\author{
Petrea Redmond \\ The University of Southern \\ Queensland
}

\author{
Peter Albion \\ The University of Southern \\ Queensland
}

\begin{abstract}
The availability of ICT job opportunities within New Zealand is continuing to grow year on year. However, there has been a decrease in the proportion of females, especially Māori and Pacifica, entering into ICT study and pursuing ICT careers. This paper explores factors that discourage participation of Māori and Pacifica high school females in ICT. Semi-structured questions were created based on a STEM cell framework to interview Māori and Pacifica females between the age of 15 and 17 years studying at high school. It was found that by year 11 Māori and Pacifica females lost interest in ICT. This came down to many factors such as perception of the industry not being diverse in people and culture, the subject being dull or boring and the subject not catering for creativity. It was clear from the results that Māori and Pacifica females were discouraged more than encouraged by perceptions and attitudes towards ICT. Māori and Pacifica females had already made their minds up by year 11 that ICT was not the right career choice to follow. Schools need to recognise the students' journey in ICT in this changing world and start promoting ICT as being creative and imaginative.
\end{abstract}

Keywords: Māori, Pacifica, females, high school, ICT.

\section{Introduction}

This paper explores a diversity problem that New Zealand has faced since the introduction of ICT into the school curriculum; Māori and Pacifica female students have a negative perception of ICT and the attitude that they do not belong. Māori and Pacifica female enrolment in ICT at high school is extremely low (Naepi et al., 2020). The research question investigates attitude and perceptions of Māori and Pacifica high school females and how that influences them regarding ICT and related career choice. In dealing with diversity, this study identifies concepts including perceptions, gender differences, culture and role models that have a negative outcome on Māori and Pacifica females entering ICT at school and as a career path.

Over the past four decades, there has been an underrepresentation of females (Mansour, 2018) in the ICT industry. In New Zealand, that representation of females in the ICT sector is mostly made up of white European New Zealanders (Soper, 2019). In 2015, Māori and Pacifica made up only $2.5 \%$ of the workers in ICT and less than $1 \%$ were skilled employees working in the ICT sector (Theodore et al., 2020). In 2018, 5635 students studied ICT courses and out of those students, 10\% of Māori and 7\% Pacifica students studied ICT related courses at universities or other tertiary institutes (Participation Rates, 2019). Of those students that do not qualify for university entrance some go on to enrol in lower qualification with other providers, but research shows that Māori and Pacifica teenagers are over-represented amongst the 75,000 youth who are not in gainful employment, education or training (Ministry of Business Innovation and Employment, 2020).

\section{Māori and Pacifica students}

New Zealand is known for its culture and is proud to be a bicultural country. However, this has been eroded over the past 50 years by the influx of immigrants from around the globe, making the population more of a multicultural society (Lomax \& Lemon, 2007). Over those years, the country has adopted many western styles, including that for education and this has caused many issues over the years with Māori and Pacifica people (Lomax \& Lemon, 2007). It was only 20 years ago that the household technology gap played a major part in Māori and Pacifica family's lives. Only $27 \%$ of Māori families and $23 \%$ of Pacifica families had access to a computer at home (Lomax \& Lemon, 2007). It has been only in the last ten years that classification of material in Māori or Pacifica languages has been made available on the internet making it more accessible for families (Google launches Maori version, 2008).

Many issues are facing Māori and Pacifica students when it comes to ICT at school. Over the past 50 years, the 
curriculum that has been used within New Zealand in high schools across the country has been based on a westernised model used by the commonwealth countries to teach students subjects, including ICT (Naepi et al., 2020). This type of westernised teaching does not embrace Māori or Pacifica culture leading to more students being left behind or excluded from schools. The pass rate for Māori and Pacifica students gaining university entrance for 2018 was only $29 \%$ across all subjects, compared to 55\% for European New Zealanders (New Zealand Ministry of Education, 2018).

In the adoption of ICT at high school, Māori and Pacifica students, especially females, are at a disproportionate rate to European New Zealand females. In 2018, only 10\% of Māori females and 6.5\% of Pacifica females took ICT at high schools across New Zealand (Participation Rates, 2019). It can also be shown from the participation rates over the last three years for ICT at school, the number of Māori and Pacifica females participating in ICT has fallen from 1150 down to 850, showing the increasing number of Māori and Pacifica females rejecting ICT at high school.

This study was guided by the research question: What are the factors that discourage participation of Māori and Pacifica females in ICT? For this research, the use of the word effects in the research question is defined by attitudes and perceptions. These attitudes to ICT come through in the research from answers the students gave in the interviews. The perceptions will be shown through social, cultural, structural and disruptive lenses.

\section{Conceptual framework}

For this research, a modified version of the conceptual framework designed by Bernhardt (2014) based on the STEM Cell model was used. This modified framework was used as a lens to make a judgement about the likelihood of Māori and Pacifica students choosing ICT for study and future career, considering the constructs of Culture, Structure, Social, and Disruptive factors. Each construct will contribute to decisions about choosing ICT as a career path. The STEM Cell 2.0 framework architecture identifies four constructs: Cultural, Structural, Social and Disruptive, each with its context and factors which may encourage or discourage participation, or present obstacles that incentivise or disincentives participation in ICT. Each of the constructs from the framework is expanded through discussion of the literature to give background into some of the perceptions and attitudes that are to be assessed through interviews.

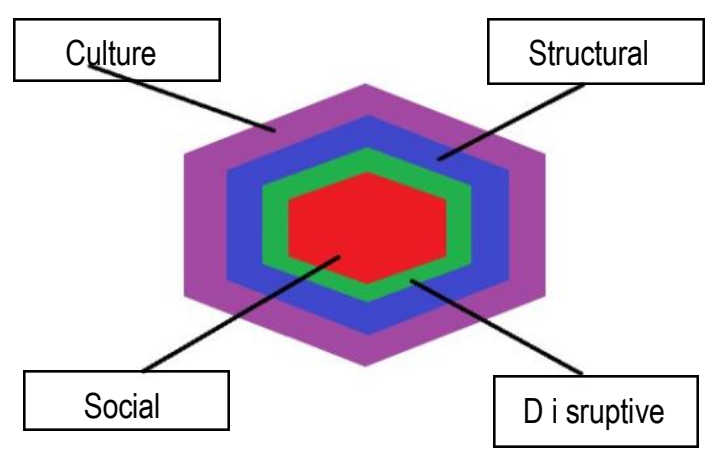

Figure 1: STEMCell2.0 Framework (Morton, 2019) architecture based on Bernhardt's 2014 STEMCell Conceptual model.

\section{Disruptive factors}

Disruptive technologies are defined "as an innovation in technology having a major effect on the old technologies, making them obsolete" (Noordin, Othman, \& Rassa, 2018, p. 6). This disruption through technology has moved the modern business landscape into a new era. Many old business models have been abandoned because of the uptake of technology, causing companies to adopt more of an agile approach to business (Noordin et al., 2018). Creating disruptive technologies has allowed the ICT sector to create new markets by providing a different set of values which overtakes existing markets, such as 'Lime' scooters which have impacted on the public transport system across New Zealand. These changes to the old business models have also impacted employment and the types of jobs available and the type of people that businesses are seeking. Organisations are struggling to find people with the skillsets to move their companies into the new era. 
Companies are finding that their internal structures are inadequate and are increasingly out of step with the external environment. The disruptive era focuses on creativity, innovation, imagination and collaboration, allowing organisations to work in an agile manner, learn continuously from success and failure and to share learning collaboratively to encourage group mentality (Noordin et al., 2018).

\section{Cultural factors}

There is no one definition that researchers have unanimously agreed upon for culture. Kroeber and Parsons (1958) defined culture as "a complex of values, ideas, attitudes and other meaningful symbols created to shape human behaviour and anti-facts of that behaviour as they are transmitted from one generation to the next" (p. 583).

Betancourt and López (1993) agreed with Kroeber and Parsons (1958) but suggested also that culture is highly variable in meaning and is learned through shared experiences with people that identify with a segment of a population. From this understanding, a child growing up in society will learn a set of values, perceptions and preferences as a basic rule through socialisation involving family/Whānau, peers, school and other factors. Culture allows society to have a sense of common identity, understanding, attitude, value and behaviour. The mix of ethnicities also adds to those cultural factors and shaping of each individual.

This exposure to different cultures within the classroom might give students a better understanding of the different types of culture. However, the schooling that all students receive in high school within public education in New Zealand is based upon the European model (Bolstad et al., 2012). This European model does not always fit comfortably with other cultures and may be one of the contributing factors to perceptions that put students off specific career paths (McCarthy, 2008). Through culture, people get a sense of their attitudes and behaviour towards different aspects of day to day life. Teenagers are starting to understand the type of person they want to be, their personalities and a sense of their self (Solomon, 2013). At this time in a teenager's life, they are also starting to think about their future and their role in society, which includes influence from family/Whānau, beliefs and career prospects.

\section{Social factors}

When school-age females start to think about their future many factors influence their perceptions and attitudes towards a particular avenue of study (Yu, Lin, \& Liao, 2017). Social factors have been defined as any variables which arise from environment, community, organisation, society, the media, technology and communication which influence an individual to think and act in a certain way (Ferguson \& Bargh, 2004). Ferguson and Bargh (2004) noted in their research that because of the number of social stimuli, situations and the response range, people's behaviour is often guided in part by the knowledge that becomes accessible through incidental means, such as unrelated experiences.

In social stereotyping, males are seen as a core part of the computer age, and many companies fall into that category by hiring to type, which is a middle-class white male (Hall, 2013). It makes it difficult for females to identify with the ICT sector and to attain some sense of belonging. It becomes even worse for females of colour because of these stereotypes, and it becomes an unconscious choice for females to reject ICT early on in their educational path (Rodriguez, 2018). Starr (2018) discussed the stereotypical traits of someone working in the ICT sector and described them as "socially awkward, unattractive and naturally intelligent" (p. 2). Starr (2018) also revealed that when people described what a person looked like, descriptors fell into categories of male, lacking social skills and obsessive. This finding agrees with prior research (Berg, Sharpe, \& Aitkin, 2018) that females' sense of belonging in ICT decreases after interacting with stereotypical people in the field (Breda, Grenet, Monnet, \& Van Effenterre, 2018).

Student career choices are influenced in many ways; role models are one of these influencers (Adya \& Kaiser, 2005). Percival (2014) found attractive looking female role models not only decreased females' interest in Science, Technology, Engineering and Maths (STEM) subjects but also decreased their beliefs in their ability to succeed at those subjects and the likelihood of studying them. Seeing attractive women as role models became demotivating to young females as their self-image does not match up. Ehrlinger et al. (2018) suggested that exposure to positive role models can be a factor for increasing female interest in STEM subjects such as information technology. Females' self-efficacy also increased when interacting with female role models (Redmond, 2006). 


\section{Structural factors}

When females think about their future and their career goals, they seek advice and guidance from many areas, beyond family and friends, two of those areas being through school and industry. School can provide many avenues of information for students, from teachers to peers (Lang, 2012). These perceptions and attitudes acquired from those sources may either have a positive or negative impact on that individual's overall attitude towards certain topics or even choice of career. At school, students from year 11 onwards are exposed more to the industry as they think about their future and start to associate their own career goals to particular industries. Albion and Tondeur (2018) recognised that teachers had a lack of understanding when it came to the use of technology and suggested that if teachers are going to be influential in regards to the quality of the education they need to embrace technology, "they need to engage in personal transformation through ongoing learning" (p. 1). Education is slow to adopt new and exciting technologies within the classroom due to the access to technology, the personal understanding of technology from the teacher, and policies that have been in place for decades. Albion and Tondeur (2018) suggested challenging these preconceptions of the old policies and developing a new vision about teachers' professional learning within ICT. They suggested allowing teachers to be able to manage and control more freely what is useful and aligns with learner outcomes. This idea aligns with a report from the Ministry of Education, New Zealand that Māori and Pacifica students have the lowest retention at high schools across New Zealand with only $71.9 \%$ of Māori and $70.6 \%$ of Pacifica students going on to complete year 13, compared to non-Māori students whose retention sits at 84.9\% (New Zealand Ministry of Education, 2018).

\section{Method}

This paper presents the results from a larger mixed-method study exploring why female students have negative perceptions of information communication technology from a New Zealand perspective. This paper will focus on the findings related to interviews with Māori and Pacifica females. Eight Māori and Pacifica high school students aged 15-17 were interviewed regarding their attitudes and perceptions of ICT with a focus on females and how that influences them concerning ICT and related career choices. The average time for each interview was 30 minutes in duration.

The first step undertaken in data analysis was to explore the data by reading through the transcripts and writing notes on each of the interviews. The researcher wanted to use a coding scheme that could be reproduced for other in-depth semi-structured interviews (Campbell, Quincy, Osserman, \& Pedersen, 2013). Ryan and Bernard (2003) suggested that analysing text involves four tasks:

- Task 1 - Discovering themes and sub-themes

- Task 2 - Decide which themes are important

- Task 3 - Build theme hierarchy

- Task 4 - Link themes to the theoretical model

From the transcription of the interviews, Table 1 shows the major themes found that impacted Māori and Pacifica females.

Table 1: Themes arising from the interviews

\begin{tabular}{|l|l|c|}
\hline Name & Description & References \\
\hline Future of ICT & What does the future of ICT look like to you & 61 \\
\hline Attitude towards ICT & These are all the attitudes that affect the interviewees regarding ICT & 142 \\
\hline Cultural Factors & Cultural factors such as home, family and background & 114 \\
\hline Perception of ICT & Perceptions of ICT & 338 \\
\hline Career Choice & Who had any impact on them choosing their career choice & 51 \\
\hline Social Factors & How factors influence through social interaction & 161 \\
\hline Structural Factors & How structural factors are driving or not driving ICT and the impact & 194 \\
\hline
\end{tabular}

\section{Results}


The following presents the research results obtained from the semi-structured interviews carried out with students from a Māori or Pacifica background. These findings present the views of students at high school in the Wellington region regarding their opinions, perceptions and influences on the questions asked of them in the interview process, of which, five were Māori and three were Pacifica. These opinions, perceptions and influences are presented along with quotes that have led to themes emerging from the participants' views. Participant quotes are presented in italics.

\section{Future of ICT}

The students discussed the concept of bigger and better, and the use of technology utilising gadgets such as VR (virtual reality) and AR (augmented reality). Student E stated that "Bigger and greater and just more things that will I guess overpower humans in a way", whereas student, I talked about "It is going to be a big future for IT, because many things are coming in like AR, VR, it is going to turn into a big thing I reckon". Student $\mathrm{H}$ discussed innovation and how it may be one area that could become big in the future "not just stuff like coding and all of that, but the innovation it brings as well, like the phones and all of that".

Whereas student A goes the complete opposite and believes that the future for ICT will be scary "I think it is going to get scary .... caused by futuristic technologies". The final theme that the majority of the students thought of when talking about the future of ICT was how useful it should be to them. Student B thought "I think it will be useful, which is probably why more people should take the subject" and Student F said, "Hopefully, it will make a massive change to everyday life". Students can see that ICT is changing and the mundane will be automated. The important finding from the interviews is the soft skills that industry require are becoming essential in ICT such as creativity and innovation as student D suggested that "I think critical thinking, problemsolving, asking good questions, being curious, and soft skills are important."

\section{Attitudes towards ICT}

Within the attitudes towards ICT, several sub-themes emerged. Student E told their story of making ICT relatable "We paired up with the robotics club and came up with a solution to use a robot to navigate the school, picking up rubbish. Both clubs had agendas that needed to be accomplished and coming together to work out a solution was interesting and fun". If schools can find a way of making ICT subjects more relatable, it may build interest from the students and increase students' self-belief and confidence in the ICT area. Student B suggested, "Yeah, like make it relatable for lots of people rather than just the people that are interested in it". Students, especially females, have lacked confidence when it comes to ICT. Females' attitudes have been to stand back and let the boys take over; however, if schools can find what excites this new generation of students when it comes to ICT, then it will bring those females back and engage them into having a go. Student E suggested that when it comes to ICT "I do not know how to phrase it but like a lack in confidence to go for it".

Students were asked the question about ICT and fun, and their attitudes towards ICT were not positive. Student $\mathrm{B}$ and $\mathrm{C}$ were put off taking ICT at high school because their perceptions and attitudes towards ICT were that it was not fun. Student B talked about "Using computers is fun, playing games is fun, understanding how they work and stuff is not fun". However, most of the time, students struggled and were put off ICT. Student C could not see any of their interests in the subject and was put off from taking up the subject at high school "It was not stimulating and did not interest me". Students F, G, H and I contradicted the other students and discussed ICT at school being fun. Student F said "It is fun to learn new ways of technology and how it is progressing" and student H said, "I find it fun because it provides a bit of a challenge".

\section{Cultural factors}

Students in the interview process were asked cultural questions that looked more closely around attitudes and perception that they had picked up from home and family members and had this in any way influenced their choice in career one way or another. With the answers given, it was split whether they perceived their background and family had been influential in their decision making for their future career path. Student A did not think it made a difference "I do not think so really", whereas student E contradicted student A by suggesting that "I think that my culture, like my family and stuff, does affect what kind of job I want". From the interviews of the students, it was clear that many of the students, especially the females, had already chosen what they thought to be their pathway from education through to a career. The majority of students had an open dialogue with their parents regarding their future, however, most parents did not have much of an influence over the 
careers chosen, and student $\mathrm{C}$ said: "I think so, in terms of actually what I do, not so much, it is more like my personal - what I am interested in". This showed that students interviewed did seek guidance and spoke to family members about their future.

\section{Perception of ICT}

Students' perception of why there is a lack of females going into the ICT field were revealed through the responses in their interviews. The student perceptions were based around confidence, lack of opportunities, and stereotyping. Student C picked on the stereotyping in ICT: “I don't want to go into an industry where I'm so outnumbered". Also, student B agreed, "I think that if there were more females, then it would be more appealing to them". Student E thought it was a confidence problem "I guess it is related to what I said before in terms of a confidence thing".

When discussing the types of jobs available in the ICT industry, the majority of the students, when pressed in the interview had little to no understanding; student A suggested: "Yeah it is like working with computers and stuff isn't it". They had limited exposure to the types of jobs available to them; student E thought "I see ICT as some programing type of thing". Only a couple of students had a better understanding, due to having family members working in the IT sector. This shows the divide between industry and the schools and the lack of understanding around ICT and the multitude of pathways that can be taken in the ICT industry.

\section{Career choice}

Students had not made their mind up about careers as such, but most had strong perceptions regarding their career path based on their experience and attitudes of ICT through school and background. The majority of the students after thinking about ICT and a career in the industry still had negative perceptions regarding ICT and student B stated "Probably not for me, it is not something that I am very interested in or wants to do" and student C said, "I do not think that from this I am going to go into ICT, but, I think it is made me think about the stereotypes and the whole - I never thought about the gender thing before". Some of the students had already chosen to follow ICT, and student H summed it up the best "I think yeah, it has reminded me of why I want to be on the ICT path."

\section{Social factors}

Many students looked towards family first for their role models rather than to the wider population, including teachers and TV personalities. Students B, C, D, F, H and I all looked to family first for their role models, whereas student E stated "Jacinda Ardern is quite a role model" and student G said "My teacher, so if it were not for him, I would not be here right now".

Student A suggested that these stereotypes are still a problem that comes from movies "It is just like in the movies and stuff like that the IT guy is always this nerdy guy with big glasses". Student C thought the stereotypical image had caused many females to reject ICT "I just think of people with glasses and long hair that they have not brushed for a week, it is a stereotype that I think when you say ICT" and student E looked at the social skills as a stereotypical problem "Like anti-social, I guess - I do not know, but yeah-I see it as they do not have social skills and they do not talk to people". Students were asked by the researcher if this stereotype of geek and nerd is still a problem for students today and many of the students agreed that this perception of ICT would have an impact on their attitudes towards ICT. This question could be considered to have a bias, as the researcher was a white male working in ICT. However, to try and reduce any bias, the interviews were conducted with a research assistant who was a Māori female.

\section{Structural factors}

Students perceived a creative side to the ICT industry, but most of the students related to what they knew of the industry, such as web and programing. Student A thought "I think they have to be creative because there are so many video games. You have to be original and stuff" and student $\mathrm{C}$ would have enjoyed ICT more if it allowed more creativity "I would have found it a lot more fun and interesting".

Students saw education and the perception of ICT from a negative aspect and their interaction with the subject through high school. Student A was put off ICT due to stereotypes at school "I think it is mostly guys; I do not 
know any females that are in any of the ICT classes and it is programing stuff, I don't understand that. When we did computing at year 9 all we did was write computer code and stuff, it was not what I thought we would be doing. I wanted to do stuff like music". The majority of students rejected the subject due to perceptions of stereotypical views of being nerdy and geeky, peers not taking the subject, being boring and a lack of interest in the subject. Student C's perception of ICT was the key that stopped them from taking ICT "I just found it boring, and I found the teacher boring and found what we did was irrelevant. I do not care about how it works". However, there were a couple of students that did do ICT; student G said: "I took a filler subject. I was way ahead of everyone else, so the teacher gave me the stuff to do, so that's why I started to learn Python. We were not supposed to start that for another two years". Student E's attitude towards ICT was very negative and said: "I don't believe that computing should be compulsory, as I found it to be very boring and a waste of time".

\section{Discussion}

The need to undertake the current research arose because of the lack of high school students, especially Māori and Pacifica females, wanting to pursue a career in ICT. Moreover, a significant study into ICT gender disparity in New Zealand has not been carried out in over a decade (Hamilton-Pearce, 2009), and the changing landscape of ICT has produced a new generation of highly connected students who have a different way of thinking than the previous generations.

The knowledge that is passed down from one generation to the next within a family environment can influence a child. Depending on the gender of that child it can have an impact on their perceptions and attitudes towards certain information learnt through interactions with family or Whānau (Coser, 1978). The results suggest these cultural identities are much stronger with Māori and Pacifica who put much more emphasis on culture than do westernised families as stated by student A would suggested that family does affect the type of industry they will go into. If Māori and Pacifica females identify more with their history and background, they are more likely to be encouraged by the interaction with their parents through feminine traits, as mothers are normally the family member who looks after the children. This can have a positive influence on the child when it comes to role models. However, it also can have a negative effect and discourage females to follow career paths that do not align with their role model (Hamilton-Pearce, 2009).

From the findings, role models only have a short life span when it comes to encouraging pathways. These findings add to the literature from Dimitriadi (2013) and suggest that more emphasis is needed at high school to encourage role models that align with ICT and females' perceptions. Māori and Pacifica relate more to someone whom they could engage with, could see certain traits that they had, could tell good stories. These findings agree with previous research (McIntyre, Paulson, Taylor, Morin, \& Lord, 2011) which found that females were more inclined to see people as a role model when they could perceive those role models as having similar traits and personalities. This showed through from the majority of students suggesting that family members were first and foremost their role model when it came to who they looked up to, especially for the girls.

Māori and Pacifica perceptions of ICT becomes distorted at high school and affects their attitudes towards the ICT industry. When negative perceptions are learnt from an early age at school it becomes very hard to change their minds. ICT should be seen as a core subject or, if not, should be intertwined into every subject. The findings indicate that Māori and Pacifica are averse to having to do ICT as a compulsory subject at school. Many factors could be the cause, such as the perceptions of the subject, the stereotyping and the lack of understanding regarding the subject. These findings agree with the literature (Bernhardt, 2014; Broadley, 2015; Dimitriadi, 2013) that those types of perceptions and attitudes are factors that discourage females from studying ICT as a subject at school and beyond. From the results it was suggested that a major concern was the stereotypical view of ICT that the majority of the girls held and the perception of the subject being dull, boring and just coding.

Māori and Pacifica students also saw creativity as a significant factor and agreed that more creativity needs to be present in the ICT subjects at school and its presence could have had a more favourable outcome to them choosing ICT as a career. Engaging students with technology that interests students such as music and social media would become easier. In this new disruptive era, companies are looking for people that have soft skills (personal attributes that enable someone to interact effectively and harmoniously with other people) ("Soft skills", 2019) and can be creative, imaginative and can solve problems. The findings from the study suggested that Māori and Pacifica thought these were good qualities to have and that creativity and imagination play an essential role in the learning environment. These findings agree with the research from Stolaki and Economides 
(2018) who discussed involving students in more of an active role and making them feel like a "partner of the teachers" rather than just students (p. 197). Everyone has stereotypical views of what a person looks like who works in the ICT industry. The words 'geek', 'nerd' and 'loner' come to mind first and foremost, then the mental image of that person who is male, white and 40 or 50 something. These are stereotypical images and views given in the literature (Adya \& Kaiser, 2005; Akbulut \& Looney, 2007; Clayton, 2006; Morton, 2013). These stereotypical views were also mirrored by the Māori and Pacifica students, regarding the type of person that works in the industry.

One notable finding from the study was related to the diversity of the workforce in the ICT industry. Māori and Pacifica females suggested that there was no place for them in the industry as they did not fit those stereotypical images, as suggested by student $\mathrm{C}$ where they thought they would be outnumbered by males. When Māori and Pacifica females viewed the workforce, they could not see people from the same culture or even the same colour. Lack of diversity has become a significant influencing factor on them wanting to pursue a career in this field. Dele-Ajayi, Shimwell, Emembolu, Strachan, and Peers (2018) agreed that this is one of the causes putting off females from entering into jobs in ICT and argued that to change these stereotypical preconceptions, companies need to expand people's image of the industry and what it means to have a career in this industry. These females can't be what they can't see. These stereotypical perceptions and attitudes of the industry are very damaging, as the majority of the females looking through this window will base their perceptions and attitudes on what they see and not by what it can offer, causing them to shy away from satisfying and well-paid careers.

One finding that came across strongly from Māori and Pacifica students was that education needs to re-think the approach to teaching ICT at school and the linear approach of the curriculum. Rata (2012) suggested that the European model that has been adopted by New Zealand is a problem for the learning preferences of indigenous cultures. It has become one of the factors why indigenous students struggle when it comes to ICT and general education. This discourages Māori and Pacifica females from education and from learning ICT. Schools need to start to re-think their approach to teaching ICT and the linear way it is presented. Māori and Pacifica females are not being allowed to express their creativity and imagination to a topic or subject that they could enjoy if only it could accommodate their passions. This came across from student $\mathrm{C}$ who would reject ICT due to the lack of creativity and not being able to follow her passion for music by creating applications that would allow her to express herself.

\section{Recommendation and conclusions}

This paper has explored the current perceptions and attitudes that either discourage or encourage year 11 Māori and Pacifica females from taking ICT as a subject at high school and as a career choice. Māori and Pacifica families' more than western families are influential over their children. Māori and Pacifica families should expose their children more to technology and the right information regarding career paths or role models that they can look to allowing them to make an informed decision on their future. Companies need to promote the soft skills that are required and not just concentrate on technical abilities. Companies should also expose students to a gender-neutral and multicultural workforce, where students can see people from their own culture and gender working in the industry.

The small number of participants interviewed reflects the limited access available to the researcher. While there are a large number of high schools in Wellington and the greater Wellington region, only six schools from the region were able to participate. Although attempts were made to include many more schools, many schools were not willing to participate in the study. Secondly, the low participation rate impacted on the ability for the finding from this study to be generalised to a broader Māori and Pacifica group.

There are far more factors that discourage than encourage Māori and Pacifica females to participate in ICT study and follow a career path. Many of these factors that discourage stem from ICT history and have been an issue for many decades. Stereotypes of the industry, such as the people, gender imbalance, jobs and perceptions are all negative in the opinion of Māori and Pacifica females. Māori and Pacifica females were also discouraged by the subject, being dull, boring and no fun. They also could not see people like themselves in the industry and again this discouraged them from entering an industry that was populated with white males. There were a couple of encouraging signs from the Māori and Pacifica females that suggested if the subject was made more interesting by allowing them to utilise their passions for other areas, then it would be fun. They also suggested that making ICT more creative and innovative would hold their interest in the subject. However, the positives do not even come close to the negatives. The balance of positive perceptions needs to increase if the industry wants to entice 
more females and diverse cultures into the sector. Because of these perceptions and attitudes, many students are rejecting ICT occupations that are perceived as incompatible with their self-belief. ICT at an educational level is being rejected by Māori and Pacifica females, and as a result, ICT companies are not seeing students coming through school and university who are interested in following a career in ICT.

\section{References}

Adya, M., \& Kaiser, K. M. (2005). Early determinants of women in the IT workforce: A model of girls' career choices. Information Technology \& People, 18(3), 230-259. doi:10.1108/09593840510615860

Akbulut, A. Y., \& Looney, C. A. (2007). Inspiring students to pursue computing degrees. Communications of the ACM, 50(10), 67-71.

Albion, P. R., \& Tondeur, J. (2018). Information and communication technology and education: Meaningful change through teacher agency. In J. Voogt, G. Knezek, R. Christensen, \& K .W. Lai (Eds.). Second handbook of information technology in primary and secondary education, pp. 381-396. Berlin: Springer.

Berg, T., Sharpe, A., \& Aitkin, E. (2018). Females in computing: Understanding stereotypes through collaborative picturing. Computers \& Education, 126, 105-114. doi:https:// doi .org/10.1016/j .compedu.2018.07.007

Bernhardt, S. (2014). Women in IT in the new social era: A critical evidence-based review of gender inequality and the potential for change. Hershey, PA: IGI Global.

Betancourt, H., \& López, S. R. (1993). The study of culture, ethnicity, and race in American psychology. American psychologist, 48(6), 629-637.

Bolstad, R., Gilbert, J., McDowall, S., Bull, A., Boyd, S., \& Hipkins, R. (2012). Supporting future-oriented learning \& teaching: A New Zealand perspective. Wellington, New Zealand: Ministry of Education.

Breda, T., Grenet, J., Monnet, M., \& Van Effenterre, C. (2018). Can female role models reduce the gender gap in science? Evidence from classroom interventions in French high schools. Paris: Sciences de l'Homme et de la Société.

Broadley, K. (2015). Entrenched gendered pathways in science, technology, engineering and mathematics:

Engaging girls through collaborative career development. Australian Journal of Career Development, 24(1), 27-38. doi:10.1177/1038416214559548

Campbell, J. L., Quincy, C., Osserman, J., \& Pedersen, O. K. (2013). Coding In-depth semistructured interviews. Sociological Methods \& Research, 42(3), 294-320. doi:10.1177/0049124113500475

Clayton, K. (2006). Attitudes towards ICT in Australian high schools. In E. M. Trauth (Ed.), Encyclopedia of Gender and Information Technology. (pp. 3384-3390). Hershey: Idea Group Reference.

Coser, R. L. (1978). The Principle of Patriarchy: The Case of" The Magic Flute". Signs: Journal of Women in Culture and Society, 4(2), 337-348.

Dele-Ajayi, O., Shimwell, J., Emembolu, I., Strachan, R., \& Peers, M. (2018). Exploring digital careers, stereotypes and diversity with young people through game design and implementation. Paper presented at the IEEE Global Engineering Education Conference (EDUCON). doi:10.1109/ED U CON.2018.8363301.

Dimitriadi, A. (2013). Young women in science and technology: The importance of choice. Journal of Innovation and Entrepreneurship, 2(1), 1-14. doi:10.1186/2192-5372-2-5

Ehrlinger, J., Plant, E. A., Hartwig, M. K., Vossen, J. J., Columb, C. J., \& Brewer, L. E. (2018). Do gender differences in perceived prototypical computer scientists and engineers contribute to gender gaps in computer science and engineering? Sex Roles, 78(1-2), 40-51.

Ferguson, M. J., \& Bargh, J. A. (2004). How social perception can automatically influence behaviour. Trends in Cognitive Sciences. 8(1), 33-39.

Google launches Maori version. (2008). Maori Language now available on Google. Retrieved from https://ww w.nzherald.co.nz/technology/news/article.cfm?c $\mathrm{id}=5 \&$ objectid=10523259

Hall, C. (2013). White, male and middle class: Explorations in feminism and history. New York: Routledge.

Hamilton-Pearce, J. (2009). Mana wāhine in information technology: Ngā kaiwhatu kākahu me te kākahu. Unpublished doctoral dissertation. Auckland University of Technology, Auckland, New Zealand.

Kroeber, A. L., \& Parsons, T. (1958). The concepts of culture and of social system. American sociological review, 23(5), 582-583.

Lang, C. (2012). Sequential attrition of secondary school student interest in IT courses and careers. Information Technology \& People, 25(3), 281-299. doi:10.1108/09593841211254330

Lomax, T. C., \& Lemon, R. (2007). Demographic Impacts in IT Education: Research Agendas. PACIS 2007 Proceedings, 132.

Mansour, N. R. (2018). Women in Computer Science: How Can We Bring More on Board? Unpublished master's thesis. Université de Sherbrooke, Quebec, Canada. Retrieved f rom 
https://eduq.info/xmlui /bi tstream/handle/11515/35994/mansour-women-in-computer-science- usherbrooke2018.pdf? sequence $=2$

McIntyre, R. B., Paulson, R. M., Taylor, C. A., Morin, A. L., \& Lord, C. G. (2011). Effects of role model

deservingness on overcoming performance deficits induced by stereotype threat. European Journal of Social Psychology, 41(3), 301-311. doi:10.1002/ejsp.774

Ministry of Business Innovation and Employment (2020). The Workforce. Retrieved from https://mbienz.shinyapps.io/labour-market-dashboard_prod/

Morton, S. (2013, October). The odd one out: Gender imbalance in tertiary ICT education. Paper presented at the 4th Annual Computing and Information Technology Research and Education New Zealand Conference, Hamilton, New Zealand.

Morton, S. (2019). Is change on the horizon for female high school students when it comes to ICT? (Unpublished doctoral dissertation), University of Southern Queensland, Australia

Naepi, S., McAllister, T. G., Thomsen, P., Leenen-Young, M., Walker, L. A., McAllister, A. L., . . . Suaaliia, T. (2020). The Pakaru 'Pipeline': Māori and Pasifika Pathways within the Academy. The New Zealand Annual Review of Education, 24, 142-159. doi:http:// orcid.org/0000-000 2-6067-9014

New Zealand Ministry of Education. (2018). Retention of students in senior secondary schools. Retrieved from Ministry of Education: https://ww w.educationcounts.govt.nz/statistics/indicators/main/student- engagementparticipation/retention_of students in_senior_secondary_schools

Noordin, M. F., Othman, R., \& Rassa, A. H. R. (2018). Social media and knowledge management disruptive technology. Paper presented at the Knowledge Management International Conference., Miri Sarawak, Malaysia.

Participation Rates. (2019). Retrieved from https://ww w.educationcounts.govt.nz/statistics/tertiaryeducation/participation

Percival, J. (2014). No George Osborne! Girls will not follow glamorous role models into science. Higher

Education Network, The Guardian. Retrieved from http://ww w.theguardian.com/higher-educationnetwork/blog/2014/may/28/no-george-osborne-girls-wil l-not-fol low-pretty-role-models-into-science

Rata, E. (2012). Theoretical claims and empirical evidence in Maori education discourse. Educational Philosophy and Theory, 44(10), 1060-1072. doi:10.1111/j.1469-5812.2011.00755.x

Redmond, P. (2006). First aid for female casualties of the information highway. Australian Educational Computing, 21(1), 26-32.

Rodriguez, R. (2018). Hacking the stereotype: The relationship between computer science identity imbalance and happiness in high school girls. Retrieved from http:/ /hdl .handle.net/ 10211.3/207133

Ryan, G. W., \& Bernard, H. R. (2003). Techniques to identify themes. Field Methods, 15(1), 85-109. doi:10.1177/1525822X 02239569

Soft skills. (2019). Retrieved from https://ww w.dictionary.com/browse/sof t-skil ls

Solomon, M. R. (2013). Consumer Behaviour: Buying, Having, and Being (10 ed). Pearson Education, Inc., New Jersey: Prentice Hall.

Soper, T. (2019). Gender gap: Women-led companies make up 8\% of the GeekWire 200 startup list. Retrieved from https:/ /ww w.geekwire.com/2019/gender-gap-women-led-companies-make-8-geekwire-200- startup-1 ist/

Starr, C. R. (2018). "I'm Not a Science Nerd!” STEM stereotypes, identity, and motivation among undergraduate women. Psychology of Women Quarterly, 42(4), 489-503. doi:10.1177/0361684318793848

Stolaki, A., \& Economides, A. A. (2018). The Creativity Challenge Game: An educational intervention for creativity enhancement with the integration of Information and Communication Technologies (ICTs). Computers \& Education, 123, 195-211. doi:https:// doi .org/10.1016/j .compedu.2018.05.009

Theodore, R., Tustin, K., Kokaua, J., Gollop, M., Kiro, C., Taylor, N., \& Poulton, R. (2020). Occupations and industries of employment of Māori university graduates: early career aspirations and destinations. Kōtuitui: New Zealand Journal of Social Sciences Online, 15(1), 140-153.

Y u, T.-K., L in, M.-L., \& Liao, Y.-K. (2017). Understanding factors influencing information communication technology adoption behavior: The moderators of information literacy and digital skills. Computers in Human Behavior, 71, 196-208. doi:https:// doi .org/10.1016/j .chb.2017.02.005

Morton, S., Redmond, P., \& Albion, P. (2020). Dealing with Diversity: Factors discouraging participation of Māori and Pacifica females in ICT education. In S. Gregory, S. Warburton, \& M. Parkes (Eds.), ASCILITE's First Virtual Conference. Proceedings ASCILITE 2020 in Armidale (pp. 252-262). https://doi.org/10.14742/ascilite2020.0103

Note: All published papers are refereed, having undergone a double-blind peer-review process. 
The author(s) assign a Creative Commons by attribution licence enabling others to distribute, remix, tweak, and build upon their work, even commercially, as long as credit is given to the author(s) for the original creation.

(C) Morton, S., Redmond, P., \& Albion, P. 2020 